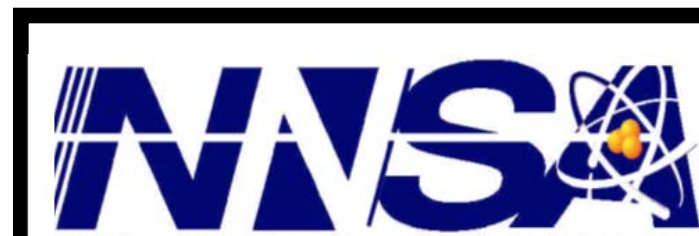

SE\&PID-13-0012

Revision: 0

\title{
Enhancements in Glovebox Design Resulting from Laboratory-Conducted Fire Tests
}

\section{Lesson Learned from the}

\section{Pit Disassembly and Conversion Facility (PDCF) Project}

June 3, 2013

Prepared for U.S. Department of Energy By: Pacific Northwest National Laboratory/URS Richland, Washington 99352

\section{UNCLASSIFIED}

DOES NOT CONTAIN UNCLASSIFIED CONTROLLED NUCLEAR INFORMATION

DC \& Reviewing Official: WG Richmond, Battelle Date: 5/16/2013
United States Department of Energy National Nuclear Security Administration Office of Defense Nuclear Nonproliferation 


\title{
DISCLAIMER
}

This report was prepared as an account of work sponsored by an agency of the United States Government. Neither the United States Government nor any agency thereof, nor Battelle Memorial Institute, nor any of their employees, makes any warranty, express or implied, or assumes any legal liability or responsibility for the accuracy, completeness, or usefulness of any information, apparatus, product, or process disclosed, or represents that its use would not infringe privately owned rights. Reference herein to any specific commercial product, process, or service by trade name, trademark, manufacturer, or otherwise does not necessarily constitute or imply its endorsement, recommendation, or favoring by the United States Government or any agency thereof, or Battelle Memorial Institute. The views and opinions of authors expressed herein do not necessarily state or reflect those of the United States Government or any agency thereof.

\author{
PACIFIC NORTHWEST NATIONAL LABORATORY \\ operated by \\ BATTELLE \\ for the \\ UNITED STATES DEPARTMENT OF ENERGY \\ under Contract DE-AC05-76RL01830
}

Printed in the United States of America
Available to DOE and DOE contractors from the Office of Scientific and Technical Information,
P.O. Box 62, Oak Ridge, TN 37831-0062;
ph: (865) 576-8401
fax: $(865)$ 576-5728
email: reports@adonis.osti.gov

\begin{abstract}
Available to the public from the National Technical Information Service, U.S. Department of Commerce, 5285 Port Royal Rd., Springfield, VA 22161 ph: (800) 553-6847 fax: $(703) 605-6900$ email: orders@ntis.fedworld.gov online ordering: http://www.ntis.gov/ordering.htm
\end{abstract}

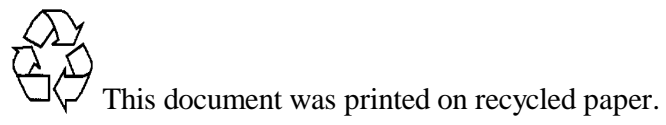




\section{PROJECT TEAM ENDORSEMENTS AND APPROVAL}

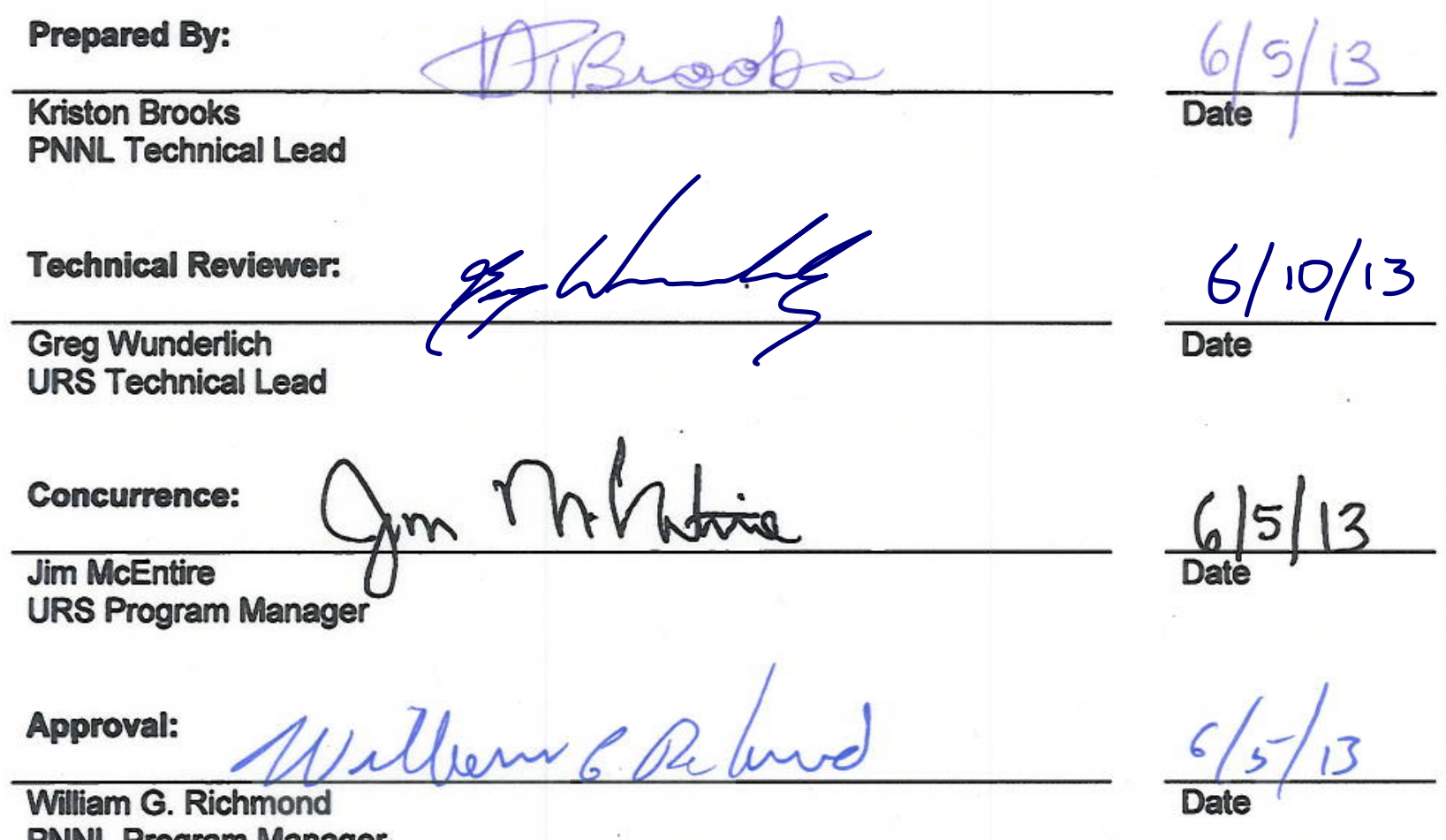

PNNL Program Manager 


\section{SUMMARY OF REVISIONS}

$\begin{array}{ccl}\text { Revision } & \text { Date } & \text { Description of Revision } \\ \text { A } & 05 / 10 / 13 & \text { Issued for contractor review } \\ \text { B } & 05 / 20 / 13 & \begin{array}{l}\text { Issued for National Nuclear Security } \\ \text { Administration (NNSA) review }\end{array} \\ 0 & 06 / 03 / 13 & \text { Initial issue }\end{array}$




\section{ACRONYMS}

\begin{tabular}{|l|l|}
\hline Acronym & Definition \\
\hline ASTM & American Society for Testing and Materials \\
\hline CVS & Containment Ventilation System \\
\hline DMO & Direct Metal Oxidation \\
\hline DOE & Department of Energy \\
\hline FHA & Fire Hazards Assessment \\
\hline HEU & Highly Enriched Uranium \\
\hline ITS & Internal Transport System \\
\hline LANL & Los Alamos National Laboratory \\
\hline LLNL & Lawrence Livermore National Laboratory \\
\hline MEKP & methyl ethyl ketone peroxide \\
\hline MT & Metric Ton \\
\hline NNSA & National Nuclear Security Administration \\
\hline PC & Polycarbonate \\
\hline PDCF & Pit Disassembly and Conversion Facility \\
\hline PMMA & Polymethyl methacrylate \\
\hline PNNL & Pacific Northwest National Laboratory \\
\hline psig & pound-force per square inch gauge \\
\hline SS & Stainless Steel \\
\hline SwRI & Southwest Research Institute \\
\hline WEP & Water Extended Polyester \\
\hline
\end{tabular}




\section{TABLE OF CONTENTS}

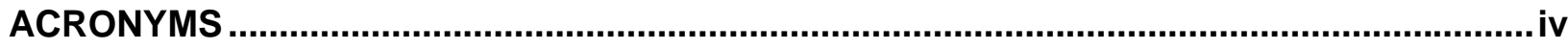

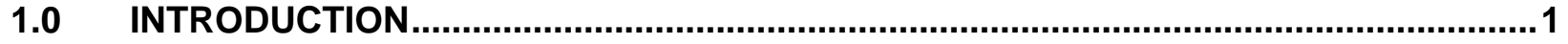

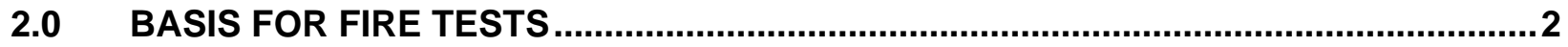

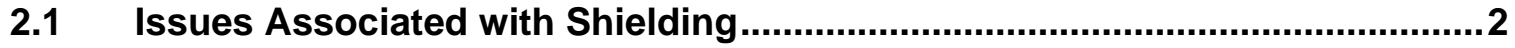

2.2 Issues Associated with Combustible Loading ............................................4

2.3 Facility Impacts Associated with High Combustible Loading ........................6

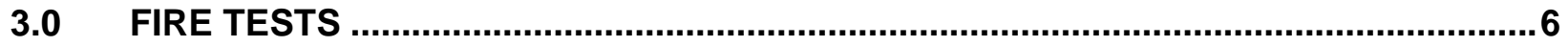

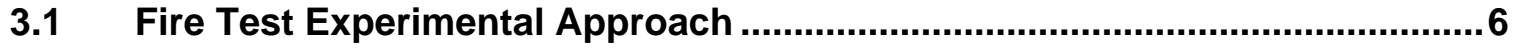

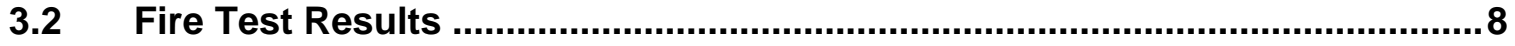

3.3 Lessons Learned from Fire Tests ............................................................12

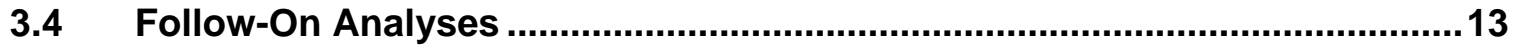

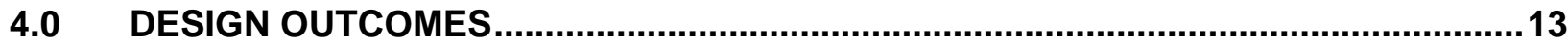

$4.1 \quad$ Window Modifications..............................................................................13

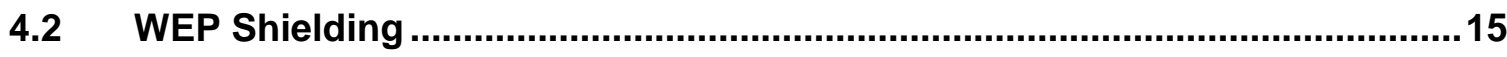

5.0 IMPLICATIONS TO FACILITY DESIGN..............................................................

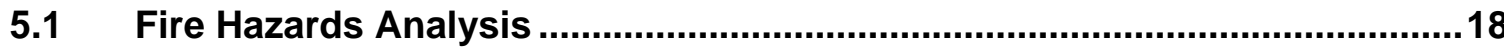

$5.2 \quad$ Safety Basis Fire Strategy …................................................................... 18

5.3 Containment Ventilation System ...........................................................18

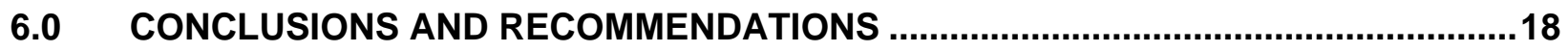

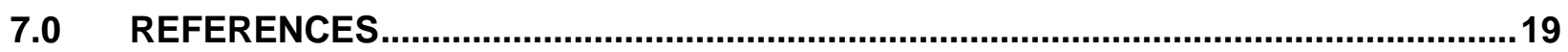




\section{LIST OF FIGURES}

Figure 1: Generic and Actual Glovebox with Locations of Shielding Specified..... 3

Figure 2: WEP and Polyethylene Beads 4

Figure 3: Window Arrangement and Glove Assembly .................................................. 5

Figure 4: Fully Assembled Shield Panel for Fire Testing …............................................ 7

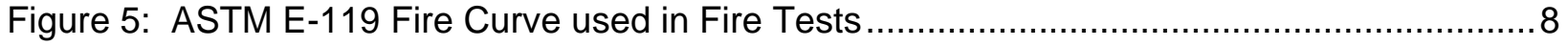

Figure 6: Post Test Picture of Test 1 .

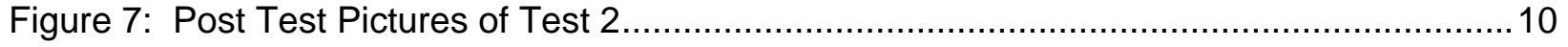

Figure 8: Glovebox Fire Test at 13 Minutes and 16 Minutes, Respectively .........................11

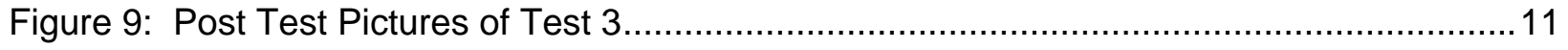

Figure 10: Drawing of Updated Window Design with New Shield Window Frame ..................14

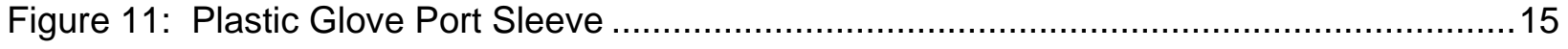

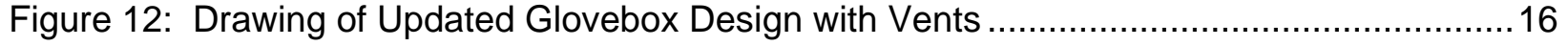

Figure 13. Reference PDCF Drawing M-PB-F-0069, Glovebox Standard Details, Shielding - Fuseable Plug, Equipment Outline

Figure 14: Isometric Drawings of Glovebox Design (a) Before and (b) After Lessons Learned

\section{LIST OF TABLES}

Table 1: Characteristics of Fire Tests 7 


\section{EXECUTIVE SUMMARY}

The primary mission of the Pit Disassembly and Conversion Facility (PDCF) Project was to disassemble nuclear weapons pits and convert the resulting special nuclear materials to a form suitable for further disposition. Because of the nature of materials involved, the fundamental system which allowed PDCF to perform its mission was a series of integrated and interconnected gloveboxes which provided confinement and containment of the radioactive materials being processed. The high throughput planned for PDCF and the relatively high neutron and gamma radiation levels of the pits required that gloveboxes be shielded to meet worker dose limits. The glovebox shielding material was required to contain high hydrogen concentrations which typically result in these materials being combustible. High combustible loadings created design challenges for the facility fire suppression and ventilation system design.

Combustible loading estimates for the PDCF Plutonium Processing Building increased significantly due to these shielding requirements. As a result, the estimates of combustible loading substantially exceeded values used to support fire and facility safety analyses. To ensure a valid basis for combustible loading contributed by the glovebox system, the PDCF Project funded a series of fire tests conducted by the Southwest Research Institute on door panels and a representative glovebox containing Water Extended Polyester (WEP) radiological shielding to observe their behavior during a fire event.

Improvements to PDCF glovebox designs were implemented based on lessons learned during the fire test. In particular, methods were developed to provide high levels of neutron shielding while maintaining combustible loading in the glovebox shells at low levels. Additionally, the fire test results led to glovebox shielding panel design modifications to mitigate pressure increases observed during the fire test in order to maintain the integrity of the WEP cladding. These changes resulted in significantly reducing the credited combustible loading of the facility.

These advances in glovebox design should be considered for application in nuclear facilities within the Department of Energy (DOE) complex in the future. 


\subsection{INTRODUCTION}

The primary mission of the PDCF was to (1) receive surplus weapons plutonium in the form of pits and other plutonium metals, (2) convert the plutonium metal to plutonium oxide, and (3) remove any residual classified attributes through blending of the converted plutonium oxide. Once the plutonium oxide was blended, it was to be sealed in storage containers for transfer to a separate facility for production of mixed oxide fuel. The PDCF was also equipped to declassify non-plutonium components and remove plutonium contamination from other surplus weapons components.

The PDCF consisted of a Plutonium Processing Building, Mechanical and Support Equipment Building, Utility Building, Fan House and Exhaust Stack, Sand Filter Structure, and Administration Building. The handling of the pits, including disassembly, conversion and packaging was performed in the Plutonium Processing Building. This building had the following operations that required gloveboxes:

- Pit Disassembly (1 shielded glovebox line)

- Special Recovery Line (1 shielded glovebox line)

- Hydride/Dehydride System (2 shielded glovebox lines)

- Direct Metal Oxidation (DMO) System (5 shielded glovebox lines)

- Oxide Product Handling System (1 shielded glovebox line)

- Product Canning System (2 shielded glovebox lines)

- Highly Enriched Uranium (HEU) Processing and Staging System (2 unshielded glovebox lines)

- Waste Management System (1 unshielded glovebox line)

- Analytical Laboratory System (multiple unshielded gloveboxes and hoods)

- Sanitization System (1 shielded glovebox line)

- Internal Transport System (ITS) (multiple unshielded connections)

The shielded gloveboxes were those that handled large quantities of plutonium metal or oxide. They were designed with 4" thick shielding in the walls and floors as well as 4" thick shielded windows. The gloveboxes were connected together using an ITS. In most cases material was to enter and exit the glovebox through an airlock. These airlocks had shielding in panels that could be opened to access the airlocks for maintenance. As a result of the hydrogenous materials used in the shielding of these gloveboxes, the combustible loading in the rooms where they were housed was high.

Combustible loading estimates for the Plutonium Processing Building increased significantly as the design matured and substantially exceeded the values used to support the fire analysis and facility safety basis. To maintain acceptable combustible loading values for these safety analyses, the combustible loading contributed by gloveboxes was de-rated by $90 \%$. No firm basis was made for this level of de-rating. To confirm de-rating assumptions, fire tests were conducted by Southwest Research Institute (SwRI) in August 2007. The purpose of the tests was to understand the performance of the combustible material found in glovebox shielding in a fire situation. Based on the test observations, the de-rating assumptions could be validated. 


\subsection{BASIS FOR FIRE TESTS}

The basis for performing the fire tests was to address the high room combustible loadings and the difficulty in quantifying the de-rating factor for the significant amounts of neutron shielding on the gloveboxes. This section will address the reasons for the need for the large amounts of neutron shielding and its resultant impact on the combustible loading. These high combustible loadings in turn would have resulted in higher levels of soot production during a fire event which would have required a larger facility confinement ventilation system.

\section{$2.1 \quad$ Issues Associated with Shielding}

In the past, facilities at DOE sites such as Rocky Flats, Hanford, Savannah River, Los Alamos National Laboratory (LANL) and Lawrence Livermore National Laboratory (LLNL) have handled plutonium. These facilities also had gloveboxes to provide containment and confinement. However, they have not required the thick shielding that was used in the PDCF. There are four reasons why this level of shielding was required in PDCF: (1) PDCF was to experience larger throughput of plutonium than most other facilities, (2) the pits to be processed at PDCF had higher doses due to the aging of the pits as compared to new plutonium processed elsewhere, (3) changes in regulations resulted in the need for neutron shielding for worker protection, and (4) differences between design limits of a new facility compared to operating limits of an existing facility.

The PDCF facility was designed to disassemble, oxidize, and containerize up to 3.5 Metric Tons (MT)/year of plutonium from pits. This is an order of magnitude larger throughput than similar work at LANL and LLNL. As a result, the worker doses were estimated to be much higher for PDCF than at these facilities. Secondly, the aging pits to be processed in PDCF had a larger ingrowth of Americium-241 as well as other high energy gamma daughter products than the plutonium that was used to produce the original pits. Thus, higher doses per pit were also anticipated. With respect to regulatory changes, during the early years when LANL and LLNL were producing pits, accurate neutron dosimetry was difficult to obtain and as a result, these facilities limited worker dose based on gamma doses alone rather than neutrons. Consequently, there was little effort to address the neutron shielding. With the promulgation of 10 CFR 835, there were regulations in place that were enforceable (and subject to Price Anderson Amendments Act fines) and resulted in additional effort to reduce the worker neutron doses. Finally, the dose limits for PDCF as a new facility in the design phase was required to be below 500 millirem per year to the whole body and 10 rem per year to the extremities. In order to build in a safety margin into the design, the design dose limits were lower than the regulatory dose limits for existing operational facilities. While the design for PDCF was required to meet new facility dose limits, there was no requirement for existing operational facilities to comply with design dose standards.

As a result of these needs for neutron shielding, the PDCF gloveboxes were well shielded (See Figure 1). The walls and floor of the glovebox were shielded with $1 / 2$ " of lead to reduce the gamma dose rate and $3 \frac{1}{2}$ " of WEP to reduce the neutron dose. Both of these materials were sealed in stainless steel (SS) cladding (3/16" thick both sides for a total shield thickness of 4$3 / 8$ "). This shield thickness was a balance between reduction in dose and obtaining acceptable ergonomics.

WEP shielding material consists of WEP 662-P Resin, a water/ethylene glycol mixture, and a boric acid/sodium hydroxide mixture. These bulk WEP liquid components were combined with methyl ethyl ketone peroxide (MEKP), a catalyst to result in a polymerized solid. Mixed with the 
bulk WEP are high density polyethylene beads (See Figure 2). A study was undertaken to determine the mix percentages to produce a solid with acceptable shielding properties. The results of this study are described in Reference 7.1.

Along with the walls being shielded, the gloveports were designed with shielded gloveport covers that provided equivalent shielding properties to the windows in which they were placed. Where shielded gloveboxes were not possible, shielded panels were installed with doors to allow access to the glovebox. These shielded panels were used especially at airlocks. Both the shielded panels and the gloveport covers contained similar levels of lead and WEP to the glovebox walls and floor. The tops of the gloveboxes were not shielded as they were sufficiently tall and the dose reflection off the ceiling sufficiently low that they did not pose an external radiation hazard to the workers in the processing rooms.

Figure 1: Generic and Actual Glovebox with Locations of Shielding Specified

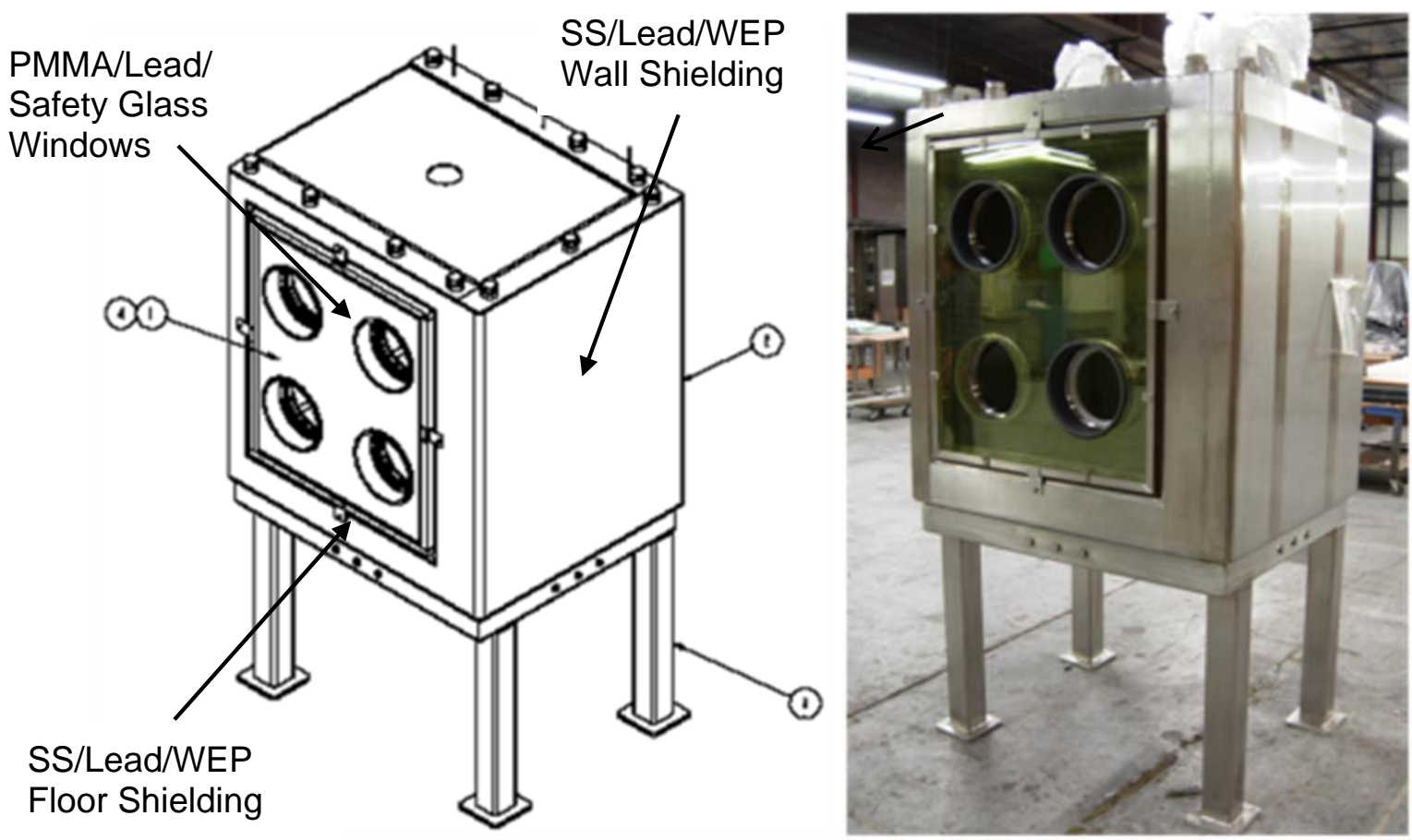

(Fully Assembled Glovebox - Fire Test Ready 2478 lbs. without WEP, 3222 lbs. with WEP) Note 1: Four brackets hold the window in place in this design.

Note 2: Identification of part numbers on the shield panel graphic (provided above) are not relevant to this document. 


\section{Figure 2: WEP and Polyethylene Beads}

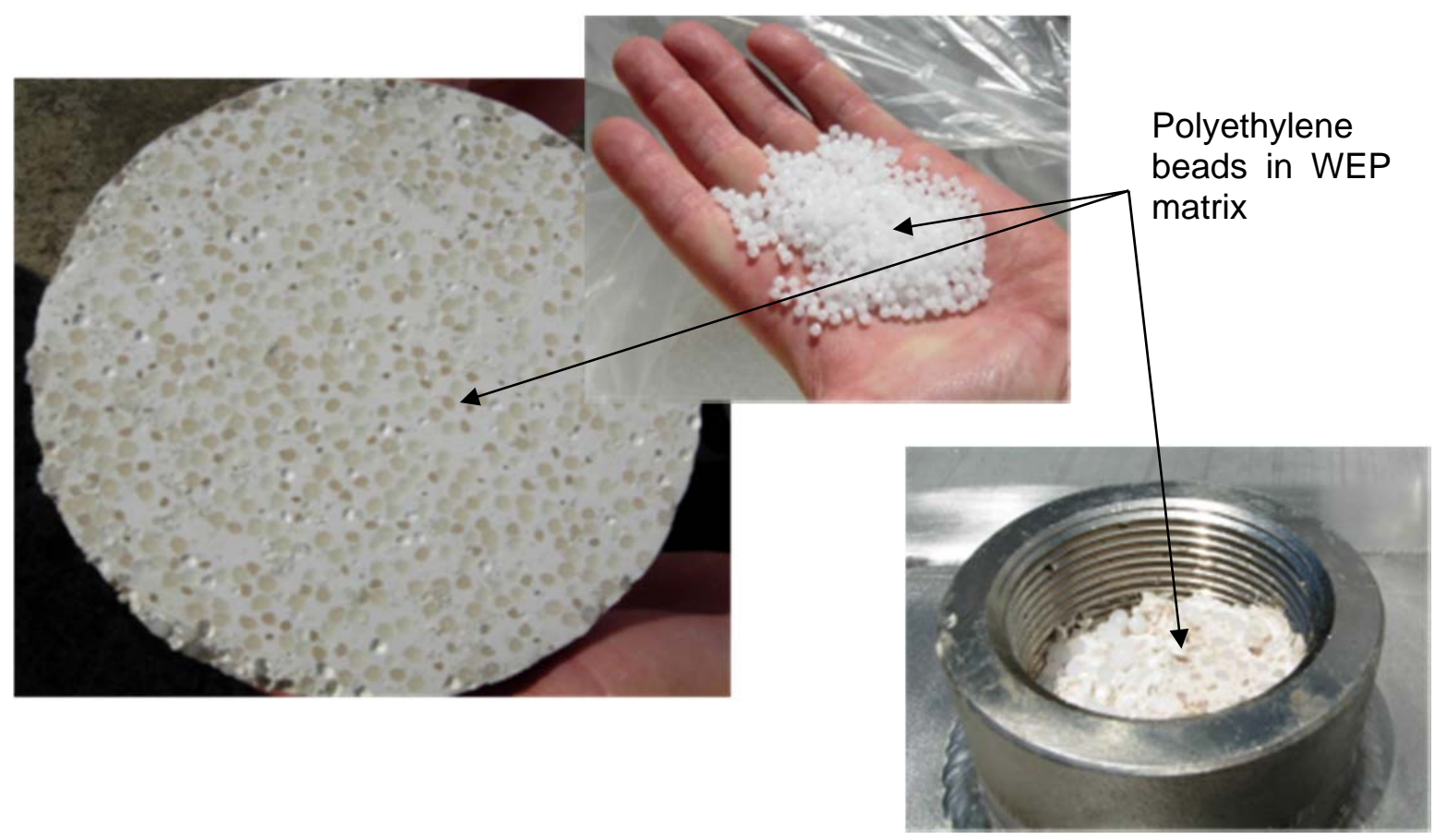

Since a large fraction of the wall of the glovebox was window, these windows were also designed to provide similar levels of gamma and neutron shielding as the walls. They had a sandwich of the following materials to produce a 4 inch composite glovebox shielding window:

- Safety glass (inner) -0.375 inches

- Polymethyl methacrylate (PMMA) (e.g. Plexiglas) -2.5 inches

- Leaded glass -1.0 inches

- Safety glass (outer) - 0.125 inches

A plastic inner glove sleeve passed through the windows at the gloveports to allow installation of the gloves as shown in Figure 3.

\subsection{Issues Associated with Combustible Loading}

As a result of this PMMA and WEP in the shielded gloveboxes throughout the PDCF, combustible loading in the rooms with gloveboxes increased beyond the combustible load design goal of nominally $7.5 \mathrm{lbs}$. wood equivalent per $\mathrm{ft}^{2}$. This value had been developed at the conclusion of PDCF Preliminary Design and was believed to incorporate sufficient margin for design evolution and transient combustible loads. Subsequent to Preliminary Design, the assessment of the combustible loading estimates for the Plutonium Processing Building increased significantly as the design matured and eventually exceeded this value, which was used to support fire analysis and facility safety basis.

To compensate for these higher combustible loading estimates, the WEP that could contribute to a fire would have been required to be de-rated by $90 \%$. This de-rating assumed that the 
majority of the WEP would not be available for combustion because it was sealed in SS cladding. Additionally, LANL had performed a fire test previously by stacking wood pallets next to a mock-up PMMA window in a glovebox. The PMMA window did not contribute to the fire which led LANL to conclude that PMMA windows would be non-combustible. To further protect the PMMA, it was sandwiched between non-combustible safety and leaded glass. As a result, the PDCF design also de-rated the PMMA at 90\%. The required combustible loading limits for the Plutonium Processing Building could be met using the $90 \%$ de-rating assumptions for WEP and PMMA; however, the basis of these assumptions was weak and was called into question during design reviews.

\section{Figure 3: Window Arrangement and Glove Assembly}

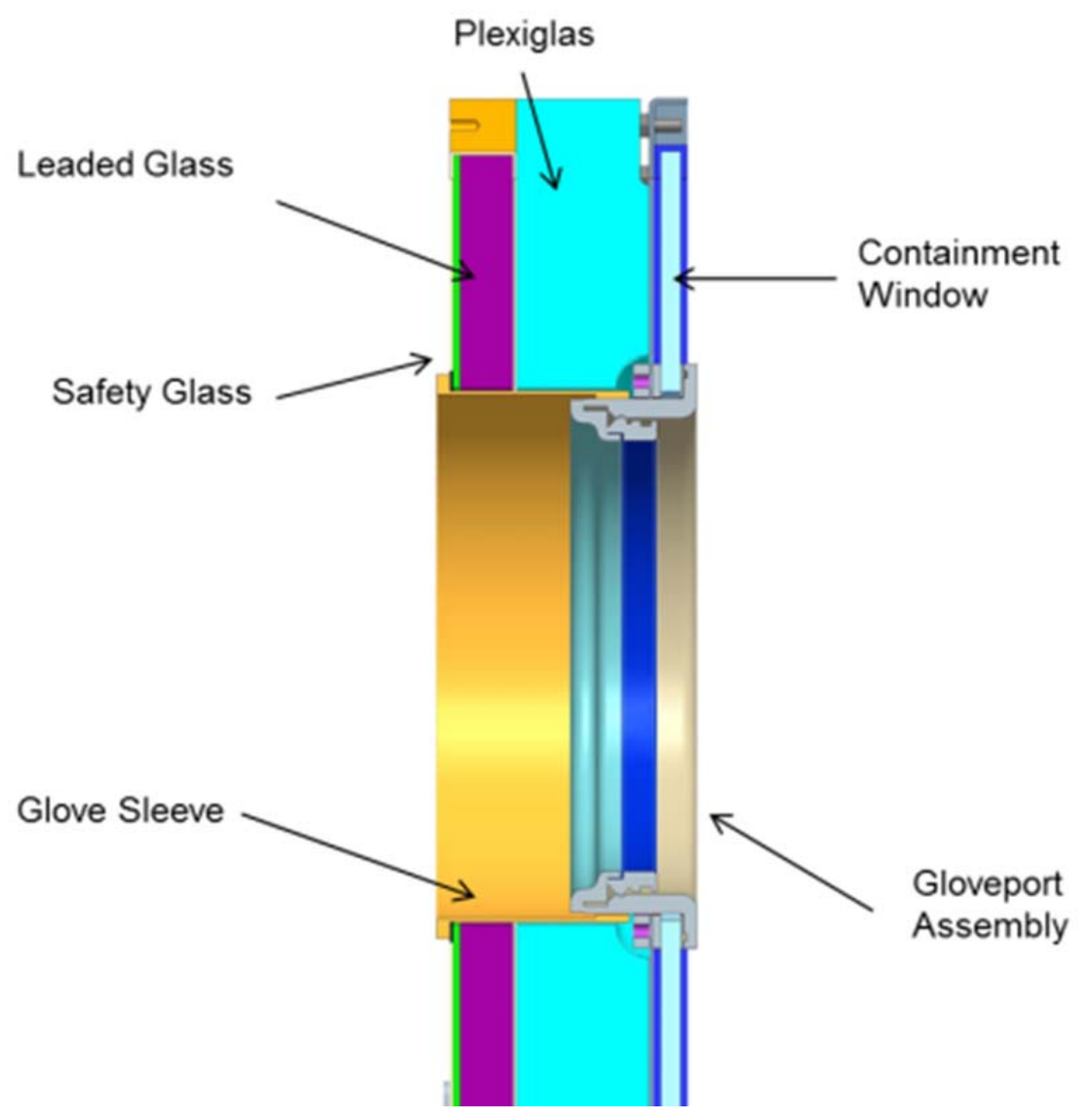

(Note: Glove Sleeve was originally plastic, but was replaced with SS as a fire test lesson learned, see Section 4.1) 


\subsection{Facility Impacts Associated with High Combustible Loading}

There were several challenges associated with high combustible loading. In the event of a fire, a higher loading would result in a higher particulate (soot) loading on the building filtration. This ultimately drove the design to a sand filter and determined its size. The higher combustible loading would also increase the heat release rate of postulated fires. This would also present greater hazards regarding flash-over potential, fire propagation and size, fire barrier performance, HVAC ductwork fire resistance, and building leak path factor values.

To evaluate the impact of combustible loading, the fire model "CFAST" was used to assess possible fire scenarios. As an initial first order analysis, all combustible materials were assumed to be consolidated into one place in a room. Additionally, the model did not credit the sprinklers. These modeling assumptions resulted in a long term fire that was oxygen starved. Only by derating the PMMA and WEP by $90 \%$ could the containment ventilation design be maintained.

\subsection{FIRE TESTS}

As a result of the concerns about the high combustible loading and the possible impact to the facility confinement ventilation system size based on the assumptions for de-rating of the WEP and PMMA, the PDCF project funded a series of fire tests to be conducted by SwRI. The rationale for these fire tests was to help understand material performance and make observations on de-rating assumptions. In this way, a more accurate assessment of the combustible loading could be made.

It was decided that the best way to perform these tests was to evaluate actual glovebox components in a large furnace using standardized time and temperature curves for ordinary combustibles. The glovebox components would contain both lead and WEP consistent with the design. This would provide a better understanding of fire behavior of metal clad WEP and composite windows in a glovebox configuration.

These tests were performed August 15-17, 2007 at the SwRI facilities in San Antonio, Texas. Each of the tests below was performed in a large horizontal furnace modified to accommodate testing of panels and gloveboxes in the upright orientation.

\subsection{Fire Test Experimental Approach}

Three tests were performed as described in Table 1.

The first test was performed with a shielding door only (See Figure 4). This door contained lead and WEP consistent with the shielding described above. It was heated using the American Society for Testing and Materials (ASTM) E-119 curve up to $800^{\circ} \mathrm{F}$ and then maintained at that temperature for 2 hours. This temperature was selected because it is below electrical cable and PMMA auto-ignition temperatures. Furthermore, the previous analysis of a "three-room fire" in the PDCF, determined to be the maximum credible fire event for the facility safety basis, was predicted to be $670^{\circ} \mathrm{F}$. The door was instrumented to measure temperature and pressure. 
Table 1: Characteristics of Fire Tests

\begin{tabular}{|l|l|l|l|}
\hline & \multicolumn{1}{|c|}{ Test 1 } & \multicolumn{1}{c|}{ Test 2 } & \multicolumn{1}{c|}{ Test 3 } \\
\hline $\begin{array}{l}\text { Glovebox Component } \\
\text { Tested }\end{array}$ & $\begin{array}{l}\text { SS shielded door } \\
\text { panel filled with WEP } \\
\text { and lead }\end{array}$ & $\begin{array}{l}\text { SS shielded door } \\
\text { panel filled with WEP } \\
\text { and lead }\end{array}$ & $\begin{array}{l}\text { Glovebox with } \\
\text { windows and WEP } \\
\text { shielding }\end{array}$ \\
\hline Temperature Curve & $\begin{array}{l}\text { ASTM E-119 up to } \\
800^{\circ} \mathrm{F} \text { and then } \\
\text { constant at } 800^{\circ} \mathrm{F}\end{array}$ & $\begin{array}{l}\text { ASTM E-119 up to } \\
2000^{\circ} \mathrm{F}\end{array}$ & $\begin{array}{l}\text { ASTM E-119 up to } \\
2000^{\circ} \mathrm{F}\end{array}$ \\
\hline Test Duration & 2 hours at $800^{\circ} \mathrm{F}$ & 3 hours & 3 hours \\
\hline $\begin{array}{l}\text { Special Testing } \\
\text { Considerations }\end{array}$ & $\begin{array}{l}\text { Thermocouple } \\
\text { Penetrations Open }\end{array}$ & No venting of WEP & $\begin{array}{l}\text { WEP cladding vented } \\
\text { at top of glovebox }\end{array}$ \\
\hline
\end{tabular}

Figure 4: Fully Assembled Shield Panel for Fire Testing
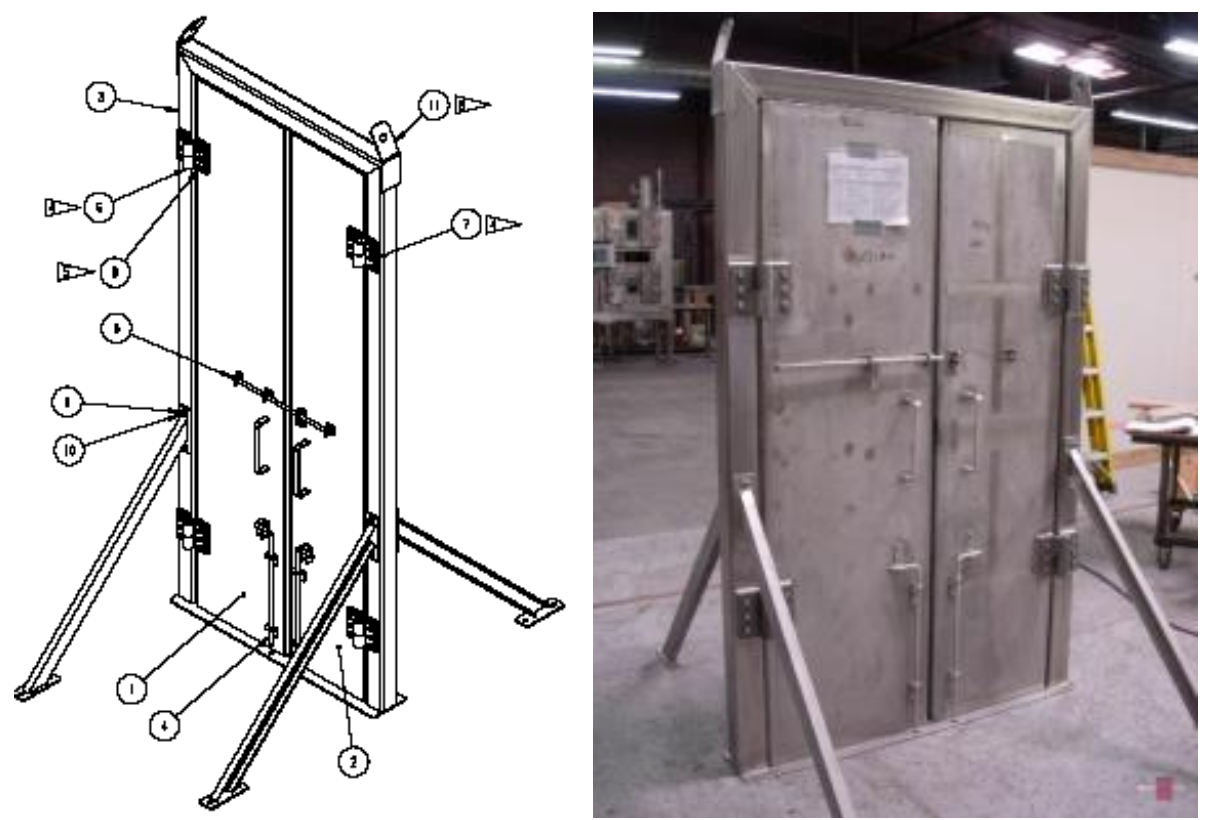

(Fully Assembled Shield Panels 1720 lbs. without WEP, 2080 lbs. with WEP)

Note: Identification of part numbers on the shield panel graphic (provided above) are not relevant to this document.

In contrast, Tests 2 and 3 were bounding events in terms of maximum temperature. These tests were conducted through the entire ASTM testing protocol E-119. [Ref. 7.2] This protocol requires heating to $2000^{\circ} \mathrm{F}$ over the course of three hours (See Figure 5). It was selected because it is a recognized standard temperature curve for ordinary combustibles. It also represents the progression over time of a typical fire and serves as a baseline for analyzing fires. In the case of Test 2, a SS shielded door similar to Test 1 was tested in the furnace. The primary difference in the design for Test 2 was to seal the thermocouple penetrations that were open in Test 1 to prevent venting of the WEP. 
Figure 5: ASTM E-119 Fire Curve used in Fire Tests

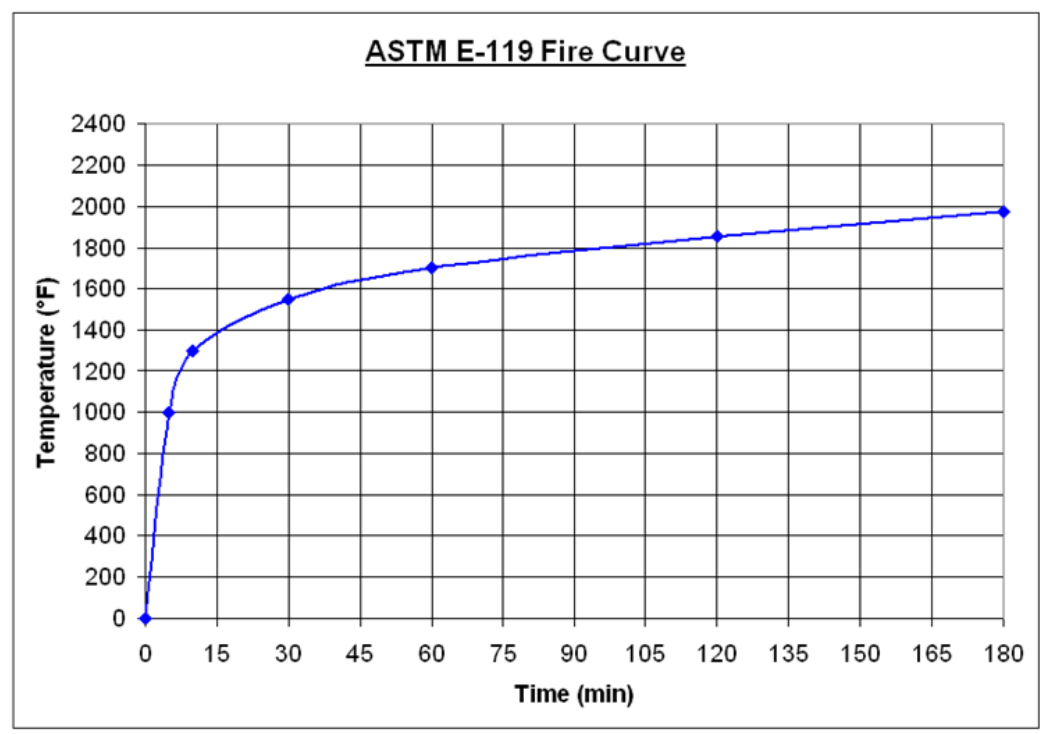

Test 3 used an entire assembled glovebox with one glove port station. The glovebox had SS clad WEP and lead composite shielding in the floor and three walls, one composite window with leaded glass, PMMA and safety glass, and even gloveports with gloves inside in the window. The WEP cladding was vented with holes at the top of each panel to prevent pressurization. Consistent with all PDCF gloveboxes, there was no shielding on the ceiling of the glovebox.

\subsection{Fire Test Results}

The results of these tests are detailed in the "WEP Final Report" [Ref. 7.3] and its addendum [Ref. 7.4] and will be summarized briefly here.

During Test 1 as the furnace was heated, pressure built up inside the panel and it bulged. A small amount of melted WEP dripped out of the thermocouple holes, down the side of the panel and onto the floor. The WEP ignited and burned both on the floor and along the panel. As the exposed WEP completely burned, the flames were extinguished until more WEP was extruded from the thermocouple holes (See Figure 6). Of the five thermocouples measuring the internal temperature of the WEP, four remained below $325^{\circ} \mathrm{F}$ and the other reached a maximum of $609^{\circ} \mathrm{F}$ in spite of the furnace temperature being maintained at $800^{\circ} \mathrm{F}$. After testing, the panel was cut open and its contents examined to determine how much of the WEP had been damaged. Results indicated only a small depth (approximately 1/4") of charring. There was approximately 1" of shrinkage of the WEP which occurred primarily near the perimeter and at the panel stiffeners but the majority of the WEP remained intact with no visible change in properties. 


\section{Figure 6: Post Test Picture of Test 1}

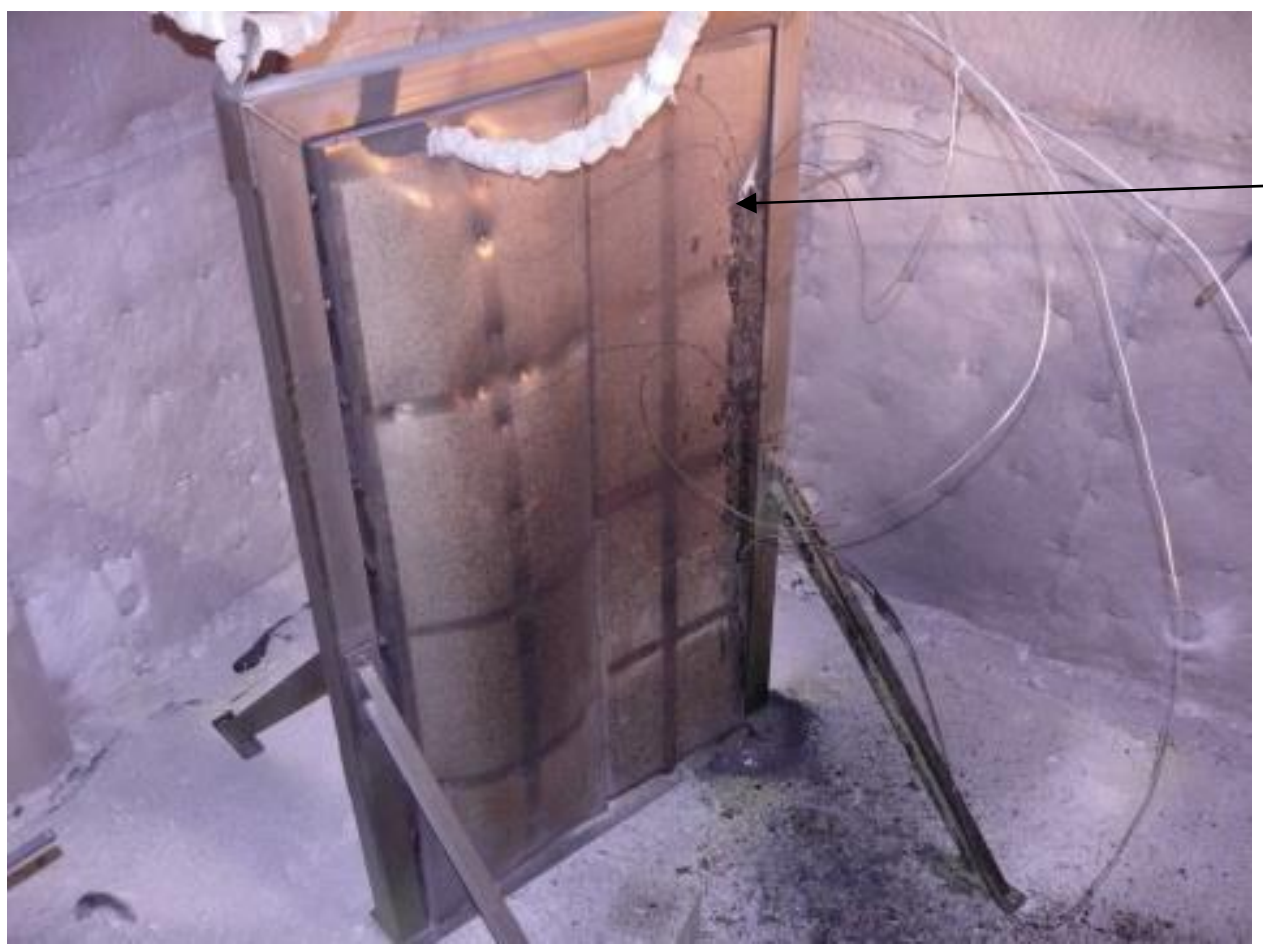

Thermocouple

hole where

WEP was

released

In contrast to Test 1, the results of Test 2 were that as the panel was heated, because it was sealed, the pressure increased until the panel bulged and then finally ruptured. The rupture occurred near the bottom of the panel when the pressure reached 149 pound-force per square inch gauge (psig). As a result of the rupture, the melted WEP and lead drained from the tear in the panel and onto the floor. As the melted WEP was directly exposed to the furnace environment, it burned and continued to burn for the remainder of the test. The flames died out only after all of the fuel value of the WEP was consumed (See Figure 7). After testing, the panel was cut open and its contents examined. In this case, the WEP was entirely charred and completely consumed. No lead remained inside the shield panel. 


\section{Figure 7: Post Test Pictures of Test 2}

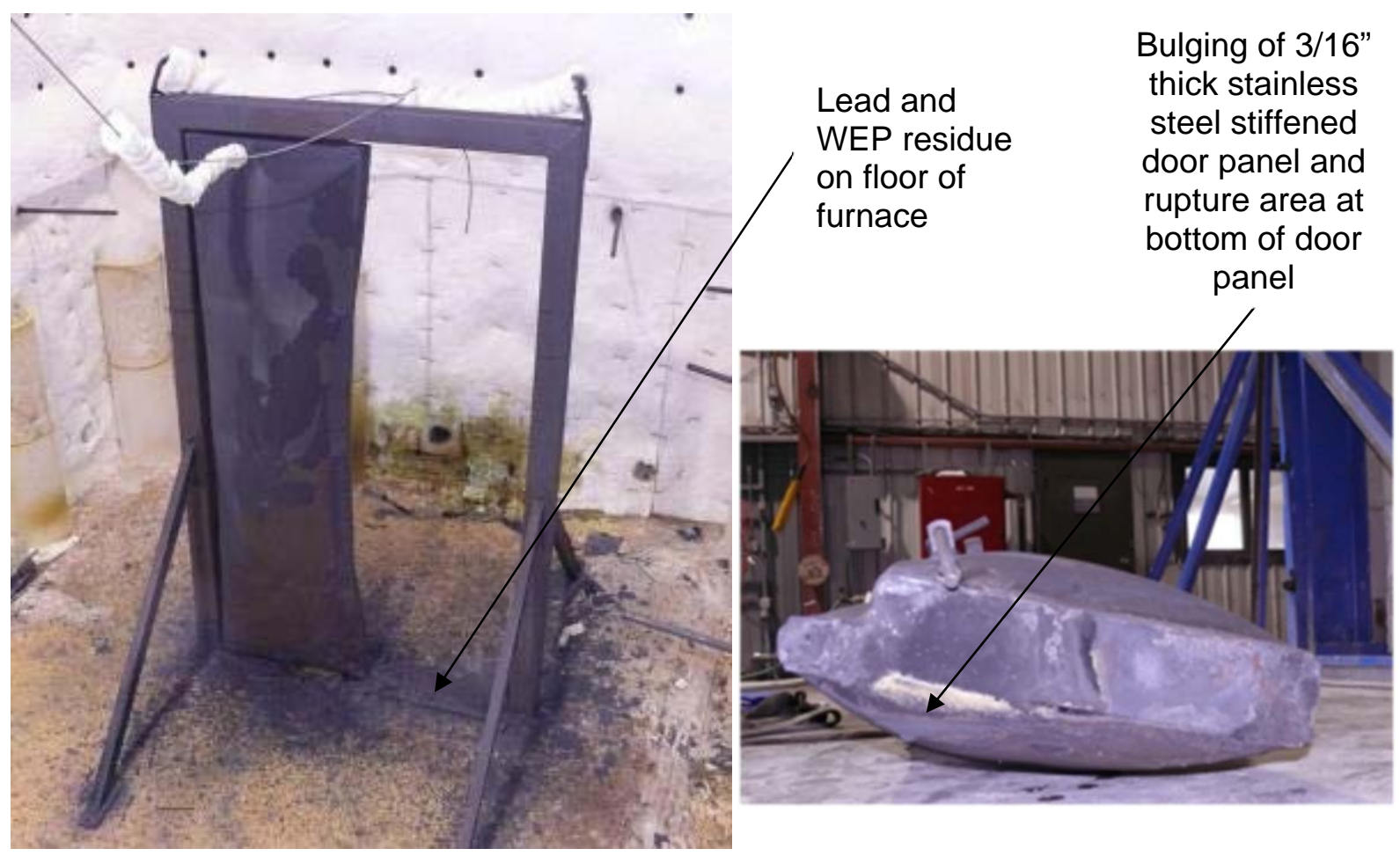

During Test 3 the gloves ignited and burned within the first minute of testing. By minute 4 , the plastic glovebox sleeves ignited and the safety glass failed. This exposed the PMMA around the glove ports which ignited and burned for about 6 minutes into the test. By 13 minutes the leaded glass failed and the PMMA began to burn across the entire face of the window. With the PMMA burning, the temperature of the furnace exceeded the fire curve and continued to rise. By minute 16, the glovebox was entirely engulfed in flames (See Figure 8). As a result of these high temperatures and molten lead pooling outside of the furnace, the test was halted prematurely at 41 minutes. The after-test evaluation of the glovebox revealed complete failure of the window (See Figure 9). The WEP inside the cladding was uniformly charred and had shrinkage similar to that seen in Test 1 . The charred material was only about $1 / 4$ " deep. Most of the WEP remained intact with no visible change in properties. The WEP shrinkage was generally 1 inch with higher values around the perimeter and at the stiffeners. 
Figure 8: Glovebox Fire Test at 13 Minutes and 16 Minutes, Respectively
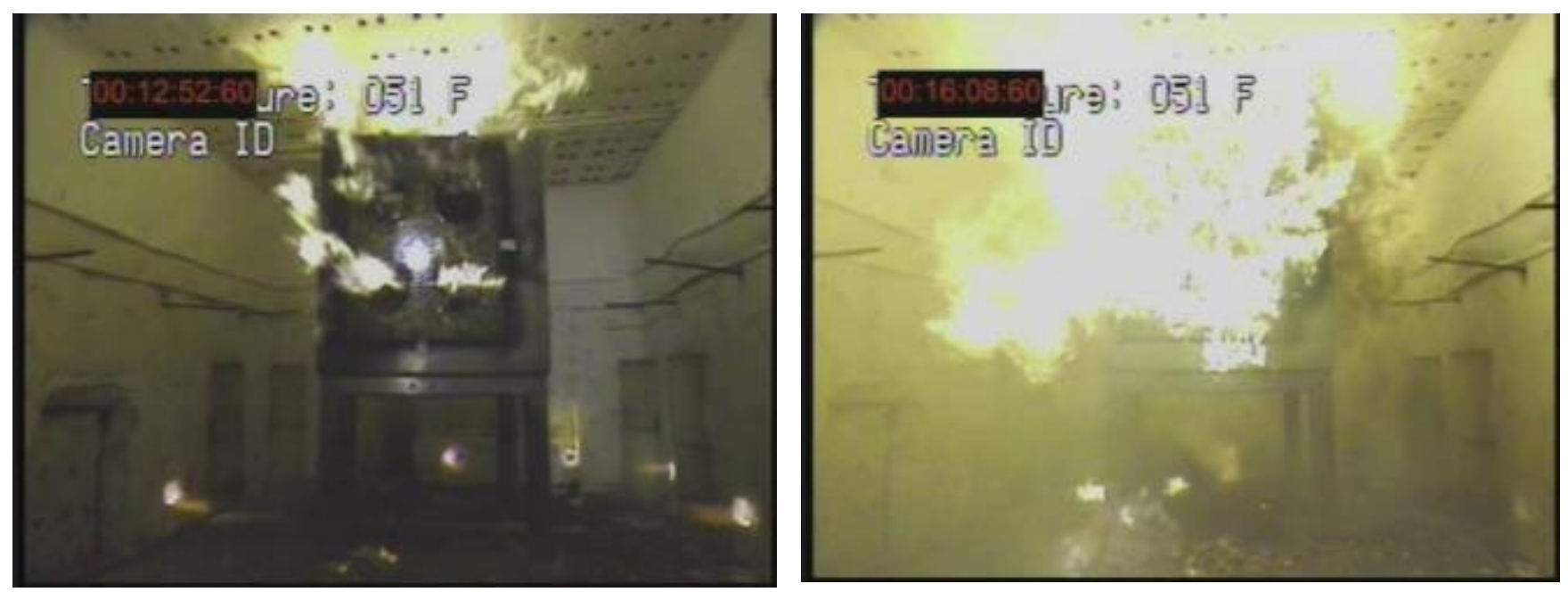

Figure 9: Post Test Pictures of Test 3

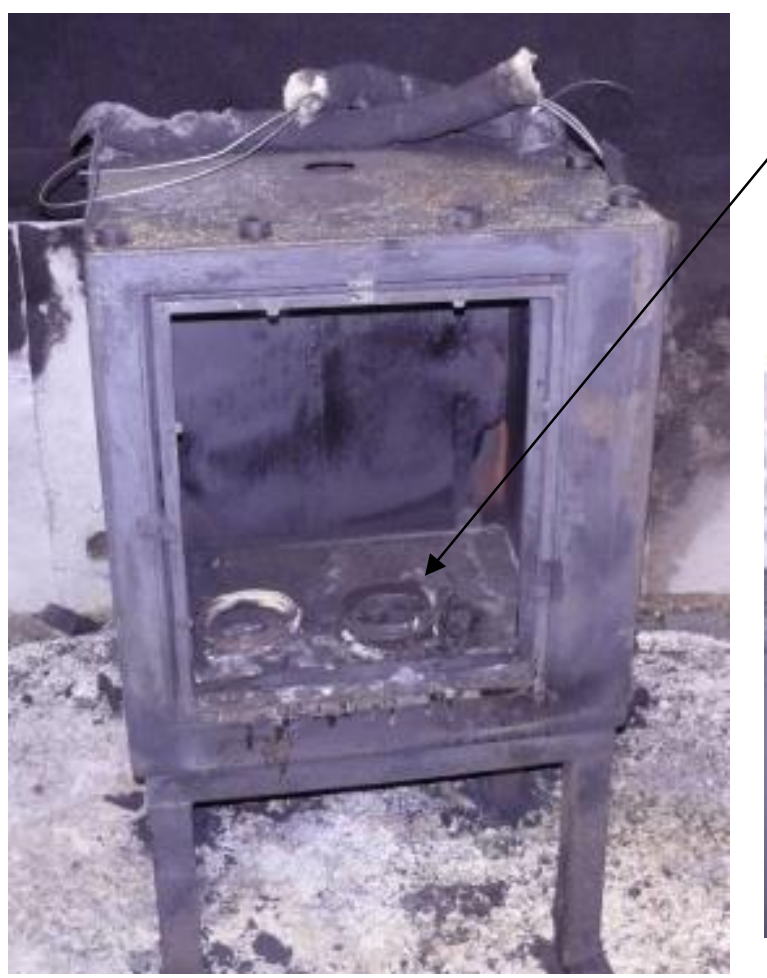

Glove port rings fallen inside of glovebox

Vent holes on top of glovebox

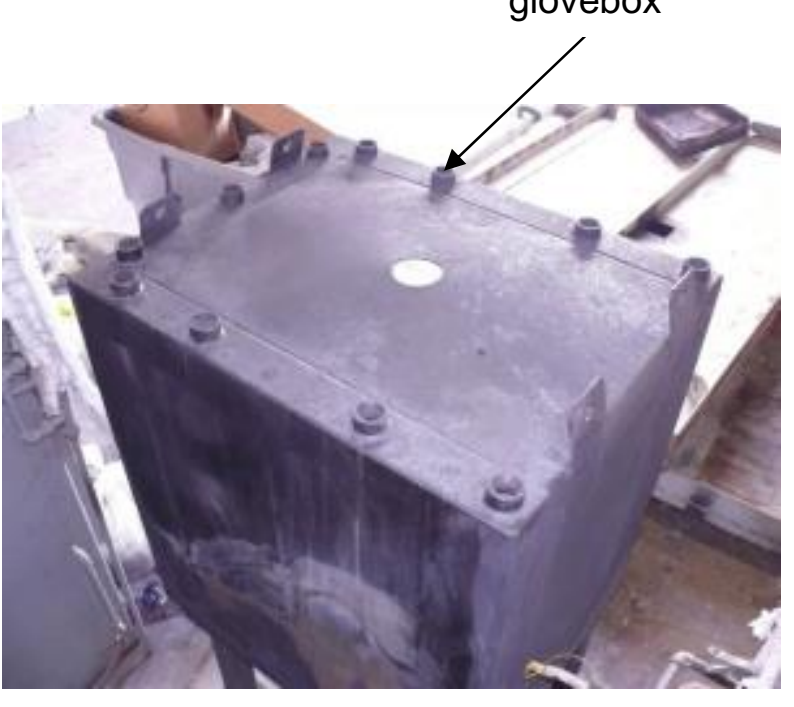




\subsection{Lessons Learned from Fire Tests}

The fire tests yielded unexpected and unanticipated results:

- The PMMA was combustible if exposed to direct flame and burned extremely hot and vigorously. Once the protective glass broke and the PMMA was exposed to fire, it burned like a high heat flux hydrocarbon fire. The previous testing at LANL which indicated that that the PMMA would not combust when exposed to flame impingement was not found in this case, most likely due to exposure of an edge of the PMMA and higher test temperatures.

- $\quad$ The WEP shielding material was found to be combustible if exposed to direct flame.

There were concerns that the fall-out of these tests would result in significant impact to not only the gloveboxes themselves but the full facility, its fire strategy and safety basis fire. However, as additional analysis was performed, the impacts were better quantified and less significant than originally thought. A few important points came out of this fire testing which ultimately led to very specific changes in the glovebox design and fire analysis. This section will deal specifically with the lessons learned.

In terms of the PMMA windows, it was found that ignition occurred on the first exposed surface, i.e., inside the glove port sleeve. This glove port sleeve was made of plastic and easily burned away to provide the initial exposure. When the PMMA in this area began to burn, the leaded and safety glass was then exposed to high thermal stresses and failed. With the protective glass layers gone, the PMMA was fully exposed and flames could then propagate across the entire surface of the window creating very high combustion temperatures. The first lesson learned was that the PMMA was required to be better protected.

The testing revealed that WEP shielding material is combustible if exposed directly to flame. However, the testing also demonstrated that fire does not propagate internal to the metal cladding. The material will char on the outside surface of the enclosed WEP but when protected from direct flame impingement, it will not burn. However, sealing the WEP completely in the cladding without a means of venting off-gassing products resulted in cladding overpressurization. As the cladding pressurized, it eventually ruptured. Based on the results of Test 2 , once the cladding is ruptured, the WEP is exposed and any areas thus exposed will burn. In the end the entire WEP contents was lost. Therefore, the second lesson learned was that the WEP should be enclosed, but this shielding (with its WEP and polyethylene beads) must be vented. Fortunately the vast majority of the gases vented are non-combustible water rather than flammable polymer vapor.

Because WEP is approximately $60 \%$ by weight water, when heated above water's boiling point, the WEP will shrink as the water evaporates from the polymeric binder. As a result, the WEP temperature stays below the exposure temperature due to water's high heat of vaporization. This combined with the insulation properties of the charred WEP result in much lower temperature inside the shielding (e.g., $330^{\circ} \mathrm{F}$ after being exposed to $800^{\circ} \mathrm{F}$ for 2 hours), thus protecting it from high temperature. The third lesson learned is that the WEP will protect itself from elevated temperatures, thus making it a good candidate for de-rating of combustible loading. 


\subsection{Follow-On Analyses}

After these initial tests, a limited number of small scale tests were performed as follow-on. Ignition testing determined that the auto-ignition temperature of the WEP was approximately $800^{\circ} \mathrm{F}$ and that it varied slightly based on the WEP composition (fractions of beads, polyester resin, and water). [Ref. 7.5] Thus, if the glovebox could be maintained less than $800^{\circ} \mathrm{F}$ in a fire scenario, the WEP along with the other significant combustibles associated with gloveboxes that have previously measured auto-ignition temperatures greater than $800^{\circ} \mathrm{F}$ (i.e., the PMMA, and wiring insulation) would not participate in the fire.

Tests were also performed to determine the heat release rate, gas composition and weight loss as a result of WEP heating at 200,400 , and $600^{\circ} \mathrm{C}$ (with beads). [Ref. 7.6] The purpose of these tests was to determine the mass loss from water as compared to hydrocarbons. The results were that at $200^{\circ} \mathrm{C}\left(392^{\circ} \mathrm{F}\right)$ the mass loss was primarily associated with water. When performing the test at $400^{\circ} \mathrm{C}\left(750^{\circ} \mathrm{F}\right)$, water was the dominant product for the first nine minutes followed by higher production of hydrocarbons. When the reaction was performed at $600^{\circ} \mathrm{C}$ $\left(1100^{\circ} \mathrm{F}\right)$, hydrocarbons immediately became the predominate product. These results demonstrate that for temperatures experienced by the WEP in fire testing $\left(330^{\circ} \mathrm{F}\right)$, the product generated would be primarily water.

\subsection{DESIGN OUTCOMES}

One of the lessons learned from the fire testing described in Section 3 was that if the maximum fire temperature is less than $800^{\circ} \mathrm{F}$, the safety basis, fire analysis, and ventilation system design and analysis for PDCF could be maintained. The lessons learned also indicated that if the combustible glovebox materials were not directly exposed to flame, they will not ignite. As a result, several glovebox modifications were made to assure this.

\subsection{Window Modifications}

The PDCF design had the PMMA protected inside the window by safety and leaded glass layers. Testing confirmed that, as long as the PMMA is not directly exposed to fire and the protective glass does not break, combustion of the PMMA does not occur. To address this, two changes were made to the window design. First, rather than having four clips around the window to hold it in place, exposing the window edges to fire, all edges of the window were encased in SS to prevent direct exposure to flame and heat. The window frame was then designed to allow for thermal expansion and thus prevent premature breakage of the safety glass as was seen to occur during Test 3. The updated window design is shown in Figure 10. Secondly, the plastic glove port sleeves were replaced with SS sleeves (See Figure 11). This eliminated the pathway for flames to directly contact the PMMA inside of the glove ports as seen during Test 3. In that test, once the plastic glove port sleeve burned, the PMMA inside of the glove ports was compromised. 
Figure 10: Drawing of Updated Window Design with New Shield Window Frame

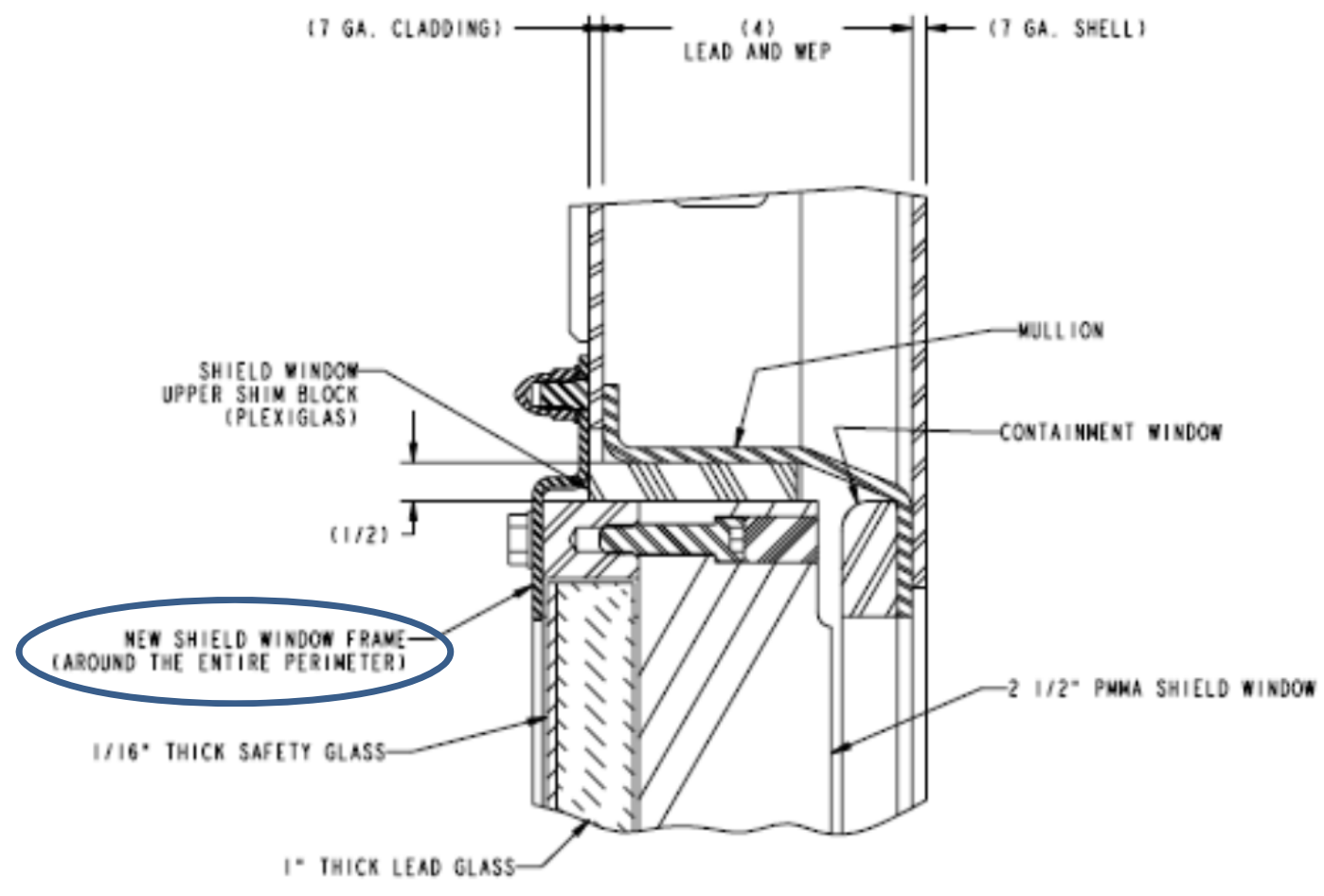




\section{Figure 11: Plastic Glove Port Sleeve}

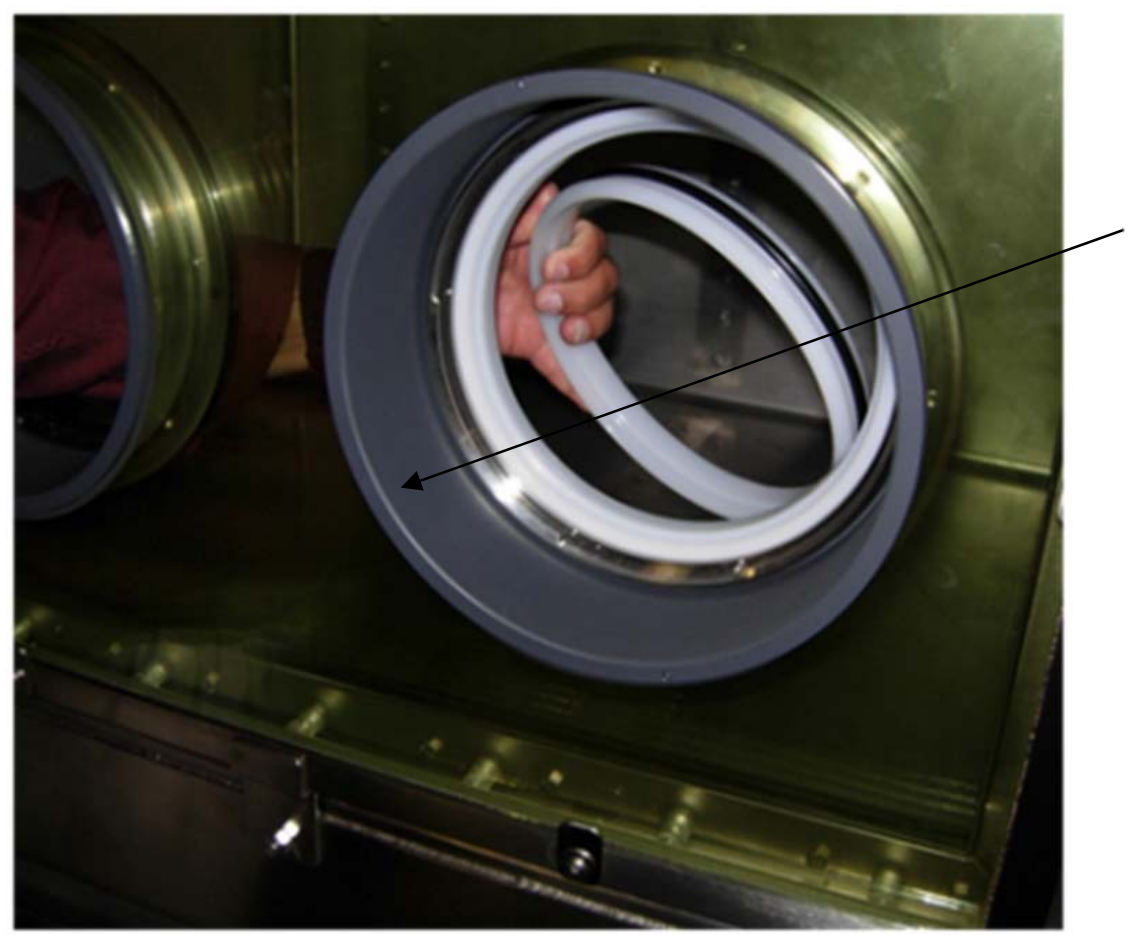

Plastic Glove Port Sleeve

A third change considered as part of the window modifications was to replace PMMA with polycarbonate $(P C)$ as the window neutron shielding material. The rationale for this change was that PC has a higher auto-ignition temperature than PMMA. However, PC was found to radiation brown more and provided less neutron shielding than PMMA. [Ref. 7.7] Furthermore, with the design changes to prevent direct exposure of the shielding window material to fire, the higher auto-ignition temperature was not required. As a result, the window neutron shielding material was not changed to PC.

\subsection{WEP Shielding}

Similar to the PMMA, testing confirmed that the WEP, while protected inside of the SS cladding, will not burn. By cladding the WEP and lead with SS, it is possible to ensure the WEP'S combustible contribution is controlled. However, if the WEP is completely sealed in the cladding, high pressures result and the cladding will rupture. To address this problem, vents were provided on the top surface of all the WEP shielding. These vents were designed into the shielding of walls, floors and glove port covers. Based on the testing that was performed at SwRI indicating water as the primary constituent, the size and actuation temperature of the vents were determined based on steam production. [Ref. 7.8] These calculations indicated that the vents needed to be slightly further apart than one vent per window bay and sized to maintain the cladding integrity based on the vapor pressure and gas generation rate. For conservatism, they were placed at a distance of one vent per window bay. These vents were to be normally sealed to prevent water evaporation which does occur if the WEP is left exposed to air. However, at a temperature of $213^{\circ} \mathrm{F}$ the vents plugs would melt and release the pressure. The design of these vent ports is shown in Figure 12 and details of the plug itself are shown in Figure 13. 
Figure 12: Drawing of Updated Glovebox Design with Vents

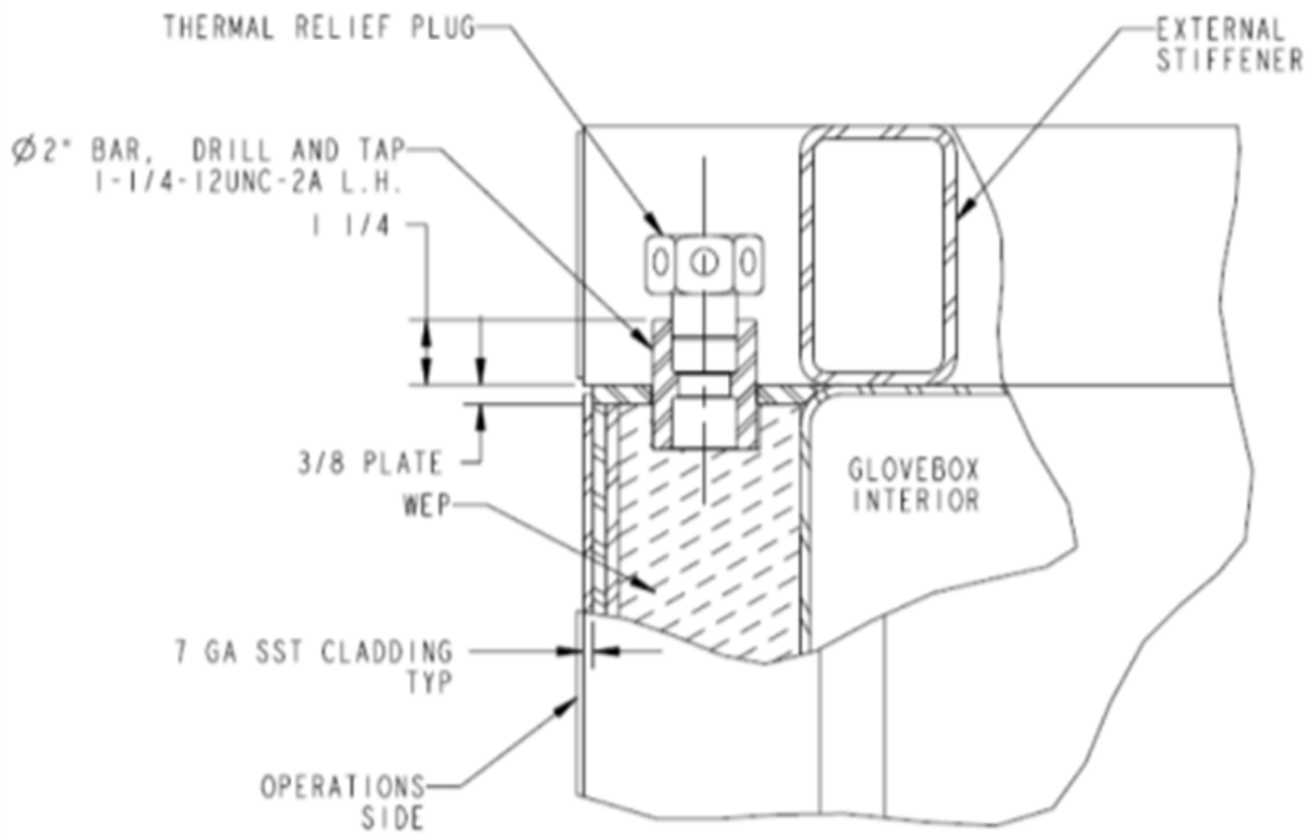

Figure 13. Reference PDCF Drawing M-PB-F-0069, Glovebox Standard Details, Shielding - Fuseable Plug, Equipment Outline
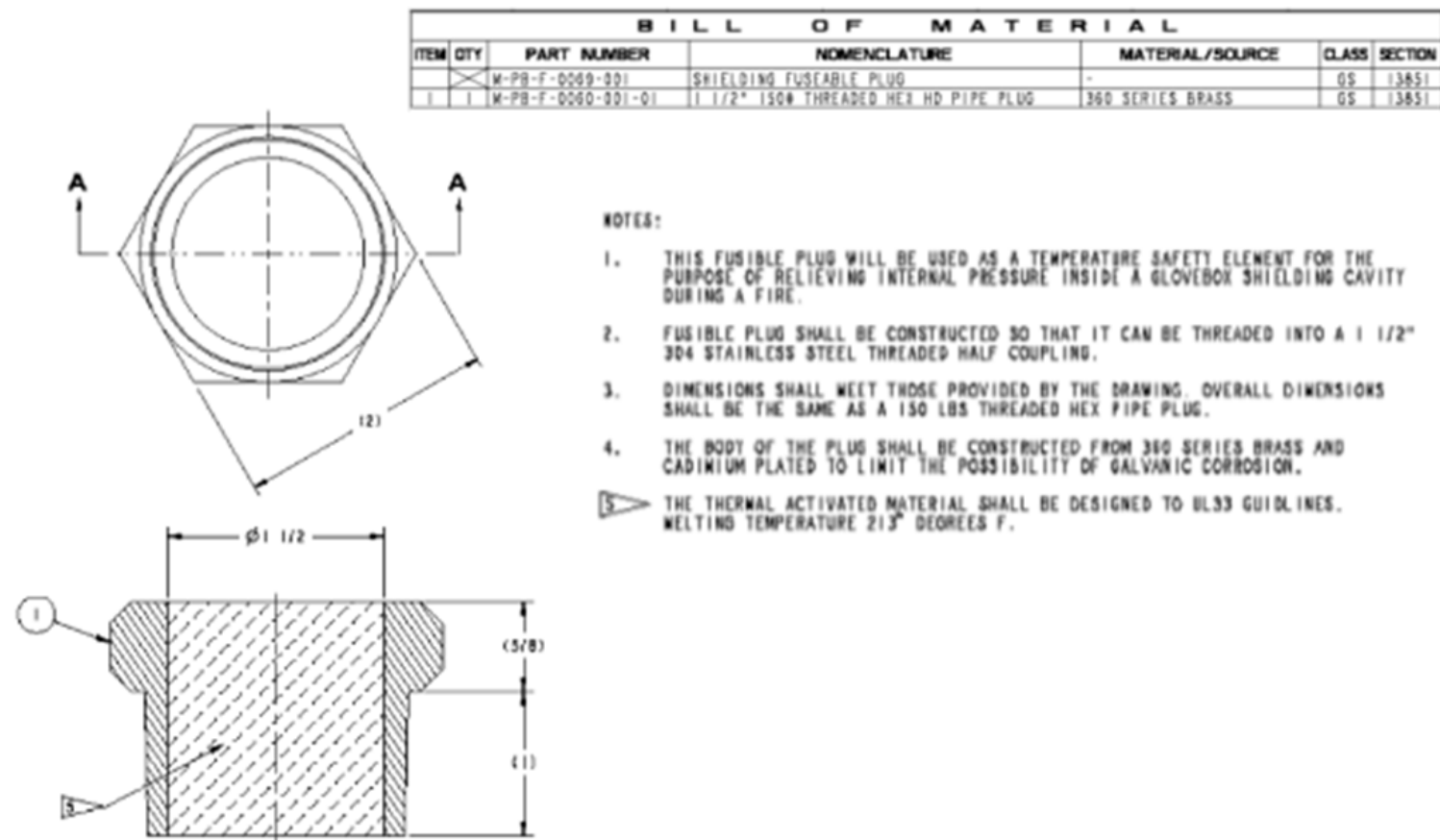
A comparison of the glovebox design before and after the lessons learned from the fire testing is shown in Figure 14. This figure summarizes the changes made in the glovebox design as a result of the fire testing.

\section{Figure 14: Isometric Drawings of Glovebox Design (a) Before and (b) After Lessons Learned}

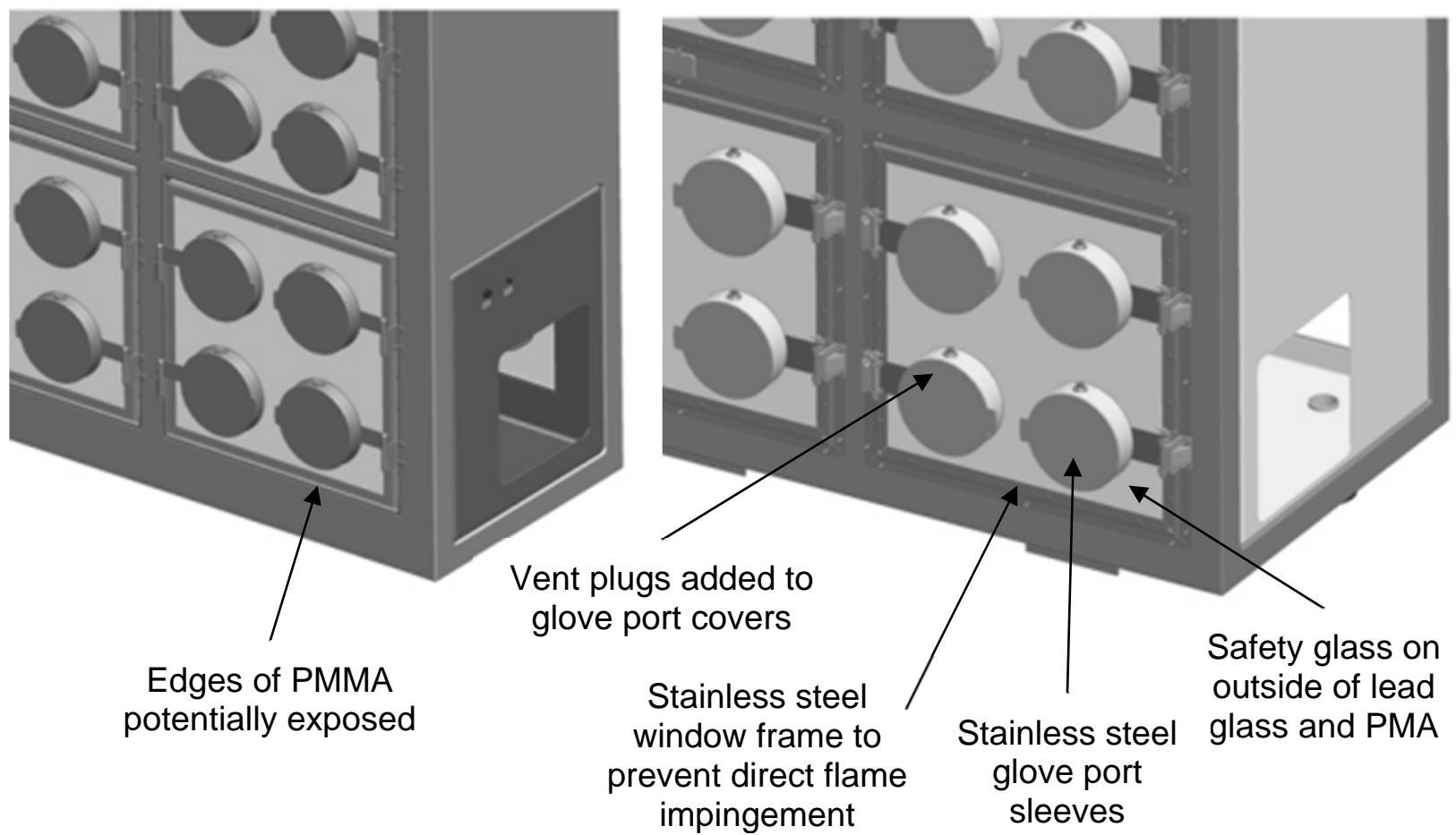

(a) Before

(b) After

(Note addition of vents on gloveport covers and new shield window frame)

\subsection{IMPLICATIONS TO FACILITY DESIGN}

Additional fire modeling of PDCF was performed as a result of the higher combustible loading. Rather than assume all combustible material in a room was consolidated together as is typical for a first order analysis, performance based modeling was done to calculate the heat release as a function of combustibles location in the room.

CFAST and HEATING models were developed to estimate temperatures, heat release rates, and soot production rates for various scenarios to determine the likelihood of propagation of the fire to other fuel packages. [Ref. 7.9] The analysis was based on a Plutonium Processing Building DMO processing room as the point of fire origin. This modeling showed that most fires would remain confined to the initial fuel packages and would not flashover. Only if PMMA were to be ignited would the entire DMO process area be encompassed and only if ITS dampers were not credited would ignition of DMO cabling be possible. Since the glovebox window design 
was revised to preclude ignition of the PMMA and the ITS dampers were credited as a fire barrier, widespread fire in the DMO room was unlikely.

As a result of this analysis, only minor to no changes were required to the Fire Hazards Assessment (FHA) safety basis fire strategy, and Containment Ventilation System (CVS). These facility documents and systems are reviewed below.

\subsection{Fire Hazards Analysis}

Based on this new fire modeling, fires that resulted in temperatures greater than $800^{\circ} \mathrm{F}$ were not likely in the Plutonium Processing Building and, as a result, no significant changes were required for the FHA. Therefore, the changes to the glovebox design allowed the glovebox shielding combustibles to be de-rated by $90 \%$ as was assumed prior to glovebox fire testing with a solid basis. [Ref. 7.10]

Beyond the glovebox design changes, administrative controls were put in place requiring that combustible loading be minimized near gloveboxes. Combustible loading near gloveboxes was not expected to be a significant concern during normal operations; however, it was expected to be an important control during maintenance when contamination tents could be constructed next to the glovebox and the glovebox windows removed.

There were concerns that fire zone boundaries and fire barriers may have to be changed due to concerns of fire propagation associated with the additional combustible loading. Additional analysis determined that changes to fire zone boundaries and fire barriers were not required. [Ref. 7.10]

\subsection{Safety Basis Fire Strategy}

There were five accidents that represented the PDCF design basis fires. Of these, only the three room fire and the post seismic fire involved gloveboxes with WEP shielding. The results of the fire test could have impacted the glovebox fire severity and duration, thus resulting in an increase in the number of rooms involved in these fires. Since the peak room temperature under these scenarios was less than $800^{\circ} \mathrm{F}$, no fire barriers were predicted to be challenged and no enhancements to the fire barriers were required.

\subsection{Containment Ventilation System}

The redesign of the gloveboxes and the result of the fire modeling demonstrated that the current analysis for the CVS could be maintained. The CVS as it was sized was sufficient to mitigate a $100 \mathrm{MW}$ or higher heat release rate. The fire modeling showed that even if gloveboxes in multiple rooms were to burn, only $22 \mathrm{MW}$ peak heat release rate would be generated. As a result, the CVS remained as a safety class system and no additional controls were added to the design as a result of the fire testing.

\subsection{CONCLUSIONS AND RECOMMENDATIONS}

Large combustible loadings from hydrogenous materials used for glovebox shielding caused concern that unreasonable demands would be placed on the PDCF safety systems. The combustibles of concern were the WEP used as shielding on the sides and bottom of gloveboxes and the PMMA used as an inner layer between the safety and leaded glass of the glovebox windows. Safety and fire hazards analyses assumed the combustible loading values for WEP and PMMA to be de-rated to $1 / 10^{\text {th }}$ of their original value because these materials would not be directly exposed to fire impingement. To determine the behavior of WEP and PMMA materials in shielding packages in a fire event and better assure that this level of de- 
rating could be applied, fire testing was performed with two shielding doors and a complete glovebox assembly in a furnace using temperatures based on the ASTM E-119 Fire Curve.

These tests identified glovebox design changes that would better prevent WEP and PMMA involvement in a facility fire. The WEP shielding design was modified to provide vents for pressure relief at regular intervals along the shielding wall. This would prevent overpressurization and ultimate failure of the SS cladding enclosing the WEP. The window frame was redesigned to allow for thermal expansion and the gloveport sleeves were upgraded from plastic to SS. In this way, the safety glass would maintain its integrity and thus the PMMA would not be directly exposed to flames.

In addition to the glovebox changes, comprehensive fire modeling was also performed using more realistic fuel loading assumptions. This modeling effort determined that most fires would remain confined to the initial fuel packages and would not flashover. As a result of the glovebox design changes and the fire modeling, the previously assumed combustible loading de-rating factor could be maintained for the WEP and PMMA. As a result of this assumption, there were only minor impacts to the facility safety basis and no real changes to the design of the safety systems.

The lessons learned from this fire testing can be applied to other nuclear facilities within the DOE complex. The glovebox changes included in the PDCF design as well as the more comprehensive modeling should be considered for facilities with significant neutron shielding to address their concerns with high combustible loadings. By applying these lessons learned, future facility designs can prevent cost and schedule variances associated with this challenge.

\subsection{REFERENCES}

7.1. Shaver, M.W. and B.A. Collins, "Specification of Water-Extended Polyester Neutron Shielding," January 2009, S-ESR-F-00049, Rev. 0, Battelle Pacific Northwest Division.

7.2. ASTM E 119-00A, 2000, "Fire Tests of Building Construction and Materials," ASTM International, West Conshohocken, PA, DOI: 10.1520/E0119-12A www.astm.org.

7.3. Bendele, Bill B., "Evaluation of Water Extended Polyester Test Sample Assemblies when Exposed to ASTM E 119-07 Time-Temperature Curve," Report No. 01.13311.04.001, Prepared for Washington Group International by Southwest Research Institute, September 21, 2007.

7.4. "Addendum to SwRI Final Report No. 01.13311.04.001," Prepared for Washington Group International by Southwest Research Institute, July 23, 2008.

7.5. "ASTM E 1354, ASTM D 1929, and IMO FTP Code Part 2 Tests of Water-Extended Polyester (WEP) and Beads," Final Report prepared for Washington Group International by SwRI, Project Nos. 01.13311.08.001 and 01.13311.10.001, August 14 and December 5-12, 2007.

7.6. "Small-Scale Fire Testing of Water-Extended Polyester for Pit Disassembly and Conversion Facility Project," Final Report prepared for Washington Group International by SwRI, Project No. 01.13311.18.001, December 4, 2009.

7.7. Richmond, W.G., "NSC-1 Revised Strategy for Combustible Controls," DCN \# 6130-47, PDFC Project, November 13, 2007.

7.8. Satkowski, Tom, "NSC-1 WEP Pressure Relief," X-CLC-F-00636, P-1, July 31, 2009. 
7.9. "Reasonably Bounding Analysis Preliminary Single and Multiple Fire Compartment Modeling Pit Disassembly and Conversion Facility," SRB-1019-08-072, Prepared for URS Washington Division by Hughes Associates, Inc., June 2009.

7.10. "Fire Risk Assessment for the Pit Disassembly and Conversion Facility Buildings 236000F \& 236001F," Supplement-F-ESR-F-00088, Revision P5, November 14, 2008. 